BOGUSŁAW ŚLIWERSKI

Akademia Pedagogiki Specjalnej im. Marii Grzegorzewskiej w Warszawie bsliwerski@aps.edu.pl

\title{
WPROWADZENIE DO PEDAGOGIKI PORÓWNAWCZEJ. TEORIA I PRAKTYKA EUROPEJSKA
}

Book review of Introduction to Comparative Pedagogy. European Theory and Praxis.

Recenzja książki autorstwa Jiřego Prokopa (2013). Wprowadzenie do pedagogiki porównawczej. Teoria i praktyka europejska. Warszawa: Instytut Wydawniczy ERICA, ss. 282.

Może ktoś wyrazi zdziwienie, że proponuję recenzję książki czeskiego pedagoga Jiřego Prokopa, która ukazała się w naszym kraju w języku polskim w 2013 r. pod tytułem - Wprowadzenie do pedagogiki porównawczej. Teoria i praktyka europejska. Powodem jest brak jakiejkolwiek reakcji na ten tytuł ze strony polskich komparatystów. Nie znaczy to jednak, że w polskim czasopiśmiennictwie nie ukazała się jak dotychczas żadna recenzja tego podręcznika, bo taki charakter ma książka akademika z Czeskiej Republiki. Odnajdziemy jedna, ale apologetyczna recenzję magistranta tego docenta z Uniwersytetu Karola w Pradze - Marka Václavíka, który najpierw streszcza poszczególne części książki, by w podsumowaniu swojej pseudorecenzji stwierdzić:

Recenzowana pozycja ma niewątpliwie wiele zalet. Tekst jest bogaty pod względem informacyjnym. Literatura została bardzo dokładnie i w sposób przenikliwy dobrana i obejmuje swoim zakresem fachowe pozycje czeskiego i polskiego środowiska pedagogicznego, a także inne obcojęzyczne źródła. Publikacja ma charakter wybitnie naukowy. Autor używa w niej terminologii z dziedziny pedagogiki porównawczej. Z pozycji tej możemy się dowiedzieć nie tylko wielu cennych i istotnych rzeczy na temat różnych systemów edukacyjnych w Europie, ale dzięki wprowadzonemu przez Autora tłu historycznemu możemy sobie uświadomić przyczyny różnic i podobieństw w poszczególnych systemach. ${ }^{1}$

Postanowiłem sprawdzić, czy rzeczywiście niniejsza publikacja jest tak świetna. Kiedy zapoznałem się z jej treścią nie miałem wątpliwości, że mamy tu do czynienia

\footnotetext{
1 Jiři Prokop, Wprowadzenie do pedagogiki porównawczej. Teoria i praktyka europejska. Warszawa, Instytut Wydawniczy ERICA, 2013, ISBN 978-83-62329-89-2 , LABOR et EDUCATIO nr 1/2013 (rec.) M. Václavík.
} 
z rozprawą quasi naukową. Została napisana na tak niskim poziomie naukowym, a nawet popularnonaukowym, że musi dziwić w naszym środowisku brak jakiejkolwiek jej krytyki ze strony komparatystów. Podręcznik Jiřv? Prokopa, który zatrudniany był już w kilku naszych uczelniach recenzowało aż trzech zagranicznych naukowców: Inna L. Fedotenko z Rosji, Petr Franiok z Czech i Bozhidara Kriviradeva z Bułgarii. Już ich dobór powinien wzbudzić międzynarodowy podziw, bo sugeruje, że zapewne świetnie znali nie tylko treść tej książki, ale i język polski, w jakim została przedłożona do druku, nie wspominając już o kompetencjach w tym zakresie autora monografii. Niestety, rozczaruja się czytelnicy, a nawet moga wpaść w depresję na skutek niemożności zrozumienia zdań, którymi opatrzone są strony tej publikacji.

Nieudolność językowa autora powinna być ostrzeżeniem przed naśladownictwem a zarazem skłonić autora i wydawcę do wycofania książki z rynku, by nikomu nie przynosiła wstydu. Bełkot, błędy gramatyczne i stylistyczne, banały, powierzchowne sądy, merytoryczne błędy, niewłaściwy dobór pojęć sprawiaja, że być może kryjące się w innym źródle wiedzy analizy mają jakikolwiek sens merytoryczny. Tego jednak nikt nie odnajdzie w tej książce. Oto fragment z pierwszego rozdziału:

Obecne społeczeństwo, to społeczeństwo wymagające od człowieka coraz więcej, jeśli chodzi o rozwój przez całe życie, poziom wykształcenia i zdolność do odpowiedzialnego pełnienia ważnych funkcji społecznych, jakich wymaga od niego życie ekonomiczne, socjalne i kulturalne. Wymagania te stawiaja $\mathrm{w}$ centrum zainteresowania także wychowanie i wykształcenie jako czynniki kierujące, które obok czynników ekonomicznych i polityczno-socjalnych determinują prawidłowy rozwój cywilizacji ludzkiej i kultury. Z naciskiem na wychowanie i wykształcenie łączy się akcent położony na te kierunki naukowe, które owymi czynnościami socjalnymi systematycznie się zajmują - na kierunki dotyczące wychowania. ${ }^{2}$

Prokop krytykuje wskazane przez Bogdana Nawroczyńskiego 4 główne zadania pedagogiki porównawczej (gromadzenie materiałów i faktów; opracowywanie monografii; porównywanie systemów; dochodzenie do zasad i prawidtowości) jako nieprzynoszące „(...) zbyt wielu wartościowych poznawczo rezultatów ${ }^{3}$. Tezy tej sam niczym nie udowadnia, gdyż - jak wynika z treści jego książki - nie zna żadnej rozprawy Nawroczyńskiego, poza jednym artykułem z 1962 r. naszego komparatysty z „Kwartalnika Pedagogicznego”. To zdumiewające, że można bez znajomości dzieł Nawroczyńskiego wyrazić taką ocenę. Na domiar tego dokonuje manipulacji opatrując ów fragment konstatacją Ryszarda Pachocińskiego z jego książki z 1998 r. , jakoby pedagogika porównawcza (...) w niewielkim dotad stopniu osiagała poziom interesujacych i niebanalnych uogólnień. Pedagogika, które aparat pojęciowy bardzo prostymi zabiegami redukuje się do potocznych wyobrażen o procesie wychowawczym, a dostarczane wyniki badań naukowych nie różnia sie

\footnotetext{
2 Tamże, s. 10 .

3 Tamże, s. 8.
} 
zasadniczo od wiedzy „,złowieka z ulicy”, nie może powiedzieć zbyt wiele na temat przebiegu zmian, szczególnie zmian interesujacych komparatystów4.

Książka Prokopa jest przykładem braku warsztatu naukowego pisarstwa i nieprzestrzegania etyki naukowej. Cytujac innych, autor ten nie podaje adresu i numeru strony. ${ }^{5} \mathrm{O}$ celach, przedmiocie i zadaniach pedagogiki porównawczej pisze w różnych miejscach w sposób eklektyczny, bez kryteriów i logiki. Do genezy tej dyscypliny nauk pedagogicznych powraca w różnych miejscach, bez jakiejkolwiek logiki. W rozdz. 1.3. prezentuje przedstawicieli pedagogiki porównawczej począwszy na Marc Antoine Jullien de Paris a na Brianie Holms skończywszy (s. 27-29), po czym po streszczeniu z różnych prac metodologicznych przesłanek tej dyscypliny naukowej pojawia się podrozdz.1.7. pt. Rozwój historyczny z przywołaniem tych samych postaci, przywołujac ich tezy, klasyfikacje, a nawet wzory pytań kwestionariuszowych do badań porównawczych szkół publicznych bez jakichkolwiek odwołań do źródeł. Przywołuje nazwiska także polskich komparatystów, ale już nie raczy uwzględnić w bibliografii ich kluczowych rozpraw.

$\mathrm{W}$ jednym miejscu eklektycznych rekonstrukcji stwierdza, że zadaniem pedagogiki porównawczej jest:

- zbieranie wiadomości o ustrojach szkolnych i pozaszkolnych oraz danych statystycznych charakteryzujących różne systemy wychowania i nauczania; - opracowanie monografii poświęconych poszczególnym ustrojom wychowania i nauczania;

- porównywanie różnych ustrojów;

- wykrywanie tego, co jest wspólne we wszystkich ustrojach, a więc zmierzanie do odkrycia pewnych zasad budowy i prawidłowości ich rozwoju. ${ }^{6}$

Tym samym powtarza to, co cztery strony dalej w swojej książce traktuje jako bezwartościowe poznawczo. Kilka stron dalej pisze zaprzeczając swoim wcześniejszym tezom:

Podstawowym zadaniem pedagogiki porównawczej jest stworzenie optymalnego systemu szkolnego, na podstawie autentycznych materiałów i dokumentów, opisu naukowego pojedynczych systemów wychowawczo-edukacyjnych, ich wskaźników $i$ komponentów, $z$ uwzględnieniem podstawowych tendencji dotychczasowego rozwoju, przystosowania do warunków obecnych i perspektyw.7 Przysłowiowego konia $\mathrm{z}$ rzędem temu, kto wyjaśni, co autor tu napisał. Zdumiewająca jest konstatacja Prokopa: Podczas porównywania systemów edukacyjnych teoria nie odgrywa najważniejszej roli, jest połaczona $z$ teoriami $i$ eksplanacjami ekonomicznymi, socjologicznymi, a takize antropologia kulturowa, demografia, naukami prawniczymi $i$ innymi. ${ }^{8}$ Kiedy jednak $\mathrm{w}$ innym miejscu swojego opracowania przywołuje czeskiego komparatystę Vaclava Pařízka stwierdza za nim, że (...) jeśli studium porównawcze ma mieć znaczenie naukowe, nie może pracować tylko $i$ wytacznie $z$ deskrypcja systemów, ale powinno taki̇e rozwijać

\footnotetext{
4 Tamże, s. 19

5 Zob. tamże, s. 20, 23-25, 30.

6 Tamże, s. 12-13.

7 Tamże, s. 21.

8 Tamże, s. 25.
} 
dziedzine teoretyczna. ${ }^{9}$ Streszczanie danych o międzynarodowych organizacjach i stowarzyszeniach niczego nie wnosi ani do nauki, ani do jakości badań porównawczych.

Kiedy wydawało się, że czymś nowym może być w tej publikacji podrozdział 2.2 zatytułowany „Problemy z porównywalnościq zjawisk pedagogicznych”, szybko się rozczarowałem, gdyż autor poświęcił go nie tylko powierzchownej, liczącej zaledwie 1,5 strony próbie wykazania różnic terminologicznych w odniesieniu do nazw typów szkół w krajach niemiecko- czy anglojęzycznych. Popełnił tu jednak tak poważne błędy w przekładzie, że nawet studenci pierwszego roku studiów pedagogicznych wykazaliby je z dużą łatwością. Muszę przytoczyć tu chociaż dwa akapity, by pokazać indolencję autora. Zdaniem Prokopa (...) w różnych językach świata te same fakty oznaczane sa bardzo różnymi terminami:

- Szkołę, która my nazywamy „średnią ogólnokształcąca”, Niemcy nazywaja „wyższą" (hóhere Schule)10, a szkołę, która my nazywamy „wyższą”, oni nazywaja „wysoką ${ }^{11 " ~(H o c h s c h u l e) . ~ W ~ S t a n a c h ~ Z j e d n o c z o n y c h ~ n a t o m i a s t ~}$ „wysoka szkoła” (high school) w języku polskim oznacza „niższą szkołę średnią".

- (...) W Szwajcarii pojęcie takie, jak „szkoła środkowa12” i „gimnazjum” (któremu w Polsce odpowiada „liceum”) mogą w niektórych kantonach oznaczać coś innego. ${ }^{13}$ (podreśl. BŚ)

W części drugiej książki, która poświęcona jest trendom w rozwoju edukacji w Europie mamy do czynienia z kompilacją różnych tekstów, streszczeń, opisów, danych bez jakiejkolwiek ich kategoryzacji czy konceptualizacji. Dane statystyczne sa, jak na książkę wydana w 2013 r., z lat 90. oraz z pierwszej dekady XXI w.. Dobierane były na podstawie tekstów innych autorów, żeby stać się przedmiotem streszczenia ich analiz. Zdaniem Prokopa kształcenie podstawowe w Polsce na drugim etapie jest kształceniem przedmiotowym, (...) $w$ ramach ścieżek edukacyjnych, bloku przedmiotowego lub ich części (klasy 4-6)14. Nie wiedział, że ścieżki edukacyjne obowiązywały w 2013 r. tylko w wybranych klasach i szkołach realizujących podstawę programową z 2002 roku, zaś w pozostałych klasach obowiązywała nowa podstawa programowa kształcenia ogólnego. ${ }^{15}$ Szkoda, że czeski pedagog nie przejął się fundamentalnymi wymaganiami, jakie stawiał badaniom monograficznym z pedagogiki porównawczej - jak pisze - jeden z największych autorytetów $\mathrm{w}$ tej dyscyplinie, profesor polskiego pochodzenia (Zygmunt Fijałkowski) z Columbia University w Nowym Jorku - George Z. F.

\footnotetext{
9 Tamże, s. 31.

${ }_{10}$ W krajach niemieckojęzycznych ten typ szkół nie dotyczy szkół wyższych tylko szkół średnich II stopnia.

11 Błąd w tłumaczeniu. W istocie Hochschule jest szkołą wyższa, a nie wysoka.

12 Tu zapewne autorowi chodziło o szkołę średnia, ale jak nie zna się języka polskiego, to tłumaczy się błędnie.

13 Tamże, s. $143-144$.

14 Tamże, s. 164.

${ }_{15}$ Rozporządzenie ministra edukacji narodowej i sportu z 26 lutego 2002 r. w sprawie podstawy programowej wychowania przedszkolnego oraz kształcenia ogólnego w poszczególnych typach szkół (Dz.U. nr 51, poz. 458, ze zm.); Rozporządzenie ministra edukacji narodowej z 27 sierpnia 2012 r. w sprawie podstawy programowej wychowania przedszkolnego oraz kształcenia ogólnego w poszczególnych typach szkół (Dz.U. z 2012 r. poz. 977).
} 
Bereday: 1) znajomość języka obszaru badań, 2) zamieszkiwanie na tym obszarze, $i$ 3) prawidtowe rozumienie przekazu kulturowego. 16

Nie traćmy zatem czasu na czytanie książki, która nie spełnia podstawowych wymogów rozpraw naukowych, a nawet podręczników akademickich. Szkoda, że jej autor nie powierzył redakcji językowej i recenzji wydawniczej specjaliście, gdyż zaprzepaściła częściowo wartościowy przecież zasób wiedzy, który jest dostępny w jego innych publikacjach wydanych w języku czeskim. Zdecydowanie wolę czytać tamte prace, by szybko zapomnieć o polskojęzycznym kiczu akademickim.

16 Tamże, s. 88. 